\title{
The Impact of Knowledge Generating Investment on GDP Growth
}

\author{
${ }^{1}$ Rita Bužinskienè, ${ }^{2}$ Dalia Rudyte, \\ ${ }^{1,2}$ Siauliai University, ${ }^{1,2}$ Siauliai State College, ${ }^{1}$ Northern Lithuania College
}

\begin{abstract}
The article analyzes the impact of knowledge generating investments on the economic growth. It was found that the main investment cash flows are intangible, education, research and development costs. Since in Lithuania the core capital is mainly formed from tangible assets and intangible assets constitute only a small part of an emerging capital, the largest part of investment goes to education, research and development, while the smallest one - to intangible assets. The research is intended to support the impact of knowledge generating investments impact on GDP growth, interconnection and level of significance.
\end{abstract}

Keywords - Education, GDP growth rate, intangible assets, Research and Development (R\&D).

\section{INTRODUCTION}

Research relevance. At the end of the twentieth century, rising interest in knowledge creation, usage and its impact on increase of economic efficiency encouraged companies and organizations to develop knowledge based activities. Business individuals reaching for competitive advantage, government representatives forming country's national strategies were encouraged to take into account the challenges provided by the knowledge economy [12]. Rate of economic growth, people's social well-being, sustainable economic development was increasingly dependent on new knowledge creation and its practical application. In Lithuania knowledge based economy started to develop in 2000, when the European Council in Lisbon adopted the Lisbon strategy, which foresaw creation of knowledge based economy in EU by 2010. The background of knowledge economy is educated and skilled people who are able to create, use and share the knowledge. Representatives of the European business expect a lot from the knowledge of economic development in the regions. More than 50 leading European companies (Siemens, Ericsson, BASF, BMW Group, Air Liquide, CIR, Fiat, Investor AB, Nestle, Nokia, Rolls-Royce, STMicroelectronics, SAP and others) from 18 countries (Germany, UK, Italy, France, Sweden, Spain, Portugal, Turkey, etc.) are grouped in the European Round Table Organization. Its goal is to encourage companies to build their activities on the grounds of knowledge to help to adapt to changing business conditions. The importance of knowledge in the current competitive environment and knowledge creation process in order to emphasize competitive advantage is noticed not only by the researchers [3], [4], [11], [13], [15], [16], [20], [21], [24], [28] but also by national and international organizations: the World Bank, the European Commission, Organization of Economic Cooperation and
Development, the World Economic Forum, Science and Education Monitoring and Analysis Centre, the Knowledge Economy Forum and others.

Research problem. Considerable attention should be given to the knowledge creation because knowledge - is the driver of the economy. As early as in 2002 in the forum "Usage of knowledge of European Union's associated countries' development" held in Paris, it was stated that Lithuania is lagging behind in knowledge economy and together with Romania and Bulgaria belongs to the group that is standing behind. The main reasons were identified: scientists are not oriented towards international technology business; science is not able to attract investment; government is incapable of developing their own education, science and technology policy; education budget is used ineffectively. The World Bank, in 2003, noted that Lithuania bearing formed knowledge assessment culture underuse its knowledge resources - people, education systems, scientists, business people and etc., resulting in a loss of some possibilities to compete internationally as well as depriving from potential growth and income opportunities. In 2012 World Intellectual Property Organization (WIPO) published "Global Innovation Index" which ranked Lithuania in the 38 position out of 141 rated countries, even more, Lithuania was behind Estonia (position 19) and Latvia (position 30). Although this index showed that Lithuania had relatively good conditions for innovation: physical infrastructure, educated people, good regulatory environment, however, it had not yielded the expected results: patents, published scientific articles, new start-ups, bigger amount of high technology goods and services in the total export. When assessing the development of knowledge based economy, it is important to evaluate properly and reflect new knowledge creation, its spread and usage, together with the creativity and innovations [7]. One cannot forget the development of information and communication technology, as well as corporate adaptability and development perspectives of innovative business. There are already models created which can be used to assess knowledge development penetration in the economy [7], [12]. However, there are no studies on the knowledge value generating investment, though it is the process of knowledge creation and its effective usage which needs the support from government, industry and academia. Therefore a problematic question arises: what kind of investment creates knowledge and what impact it has on the country's economic growth?

Research object. Knowledge generating investment. 
$2014 / 26$

Research aim. To determine knowledge generating investment and its impact on GDP growth.

Research goals.

1) To describe knowledge generating investment.

2) To assess knowledge generating investment's impact on GDP growth in Lithuania.

Research methods. This article is based on systematic science literature analysis, general and logical analysis, synthesis, analogy, generalization, classification, cataloguing, comparison methods, correlation and regression analysis.

\section{KNOWLEDGE GENERATING INVESTMENT}

Knowledge economy is the economy which leads to the growth of not only investment in physical capital, but is especially important in knowledge creation and its use. New knowledge creation - it is a creation of new ideas, products, processes, concepts, etc. [27]. Due to the transformation of knowledge properties economic value is created, which determines the performance of productivity growth and creation of new knowledge with its effective use encourages economic growth of states [12]. Running out of traditional natural resources, economic growth has increasingly been assured using information resources [1]. Most investment goes to information, information technology, e-commerce, software, marks, patents, rights, research and innovations, customer needs analysis, consumer base which is based on knowledge. With every day knowledge is becoming a more important intangible resource that determines success of people and organization, efficiency of investment, economic development, and even the power of the states. Thus, by means of modern economic conditions, knowledge is conceded as a valuable resource in the organization's work. In today's economy intangible resources are increasingly valued, the more experience, skills, higher education the staff has, the higher value organization gains [18]. Consequently, investment in human resources, research and development and in new technologies is becoming an important part of organization's activities, therefore this investment is called intangible. Intangible investments in scientific literature are characterized as innovation investment [25]. This investment includes scientific and technical progress investment, human capital, social investment, indirect advertising. In addition, it is often wrongly assumed that innovation is a total originality, i.e., absolutely everything that was unknown before. In fact, innovation typically is $99 \%$ of things known long before and just $1 \%$ is something new. Intangible investment identifies as investment into intangible assets which can be patents, licenses, research work and etc. Lithuanian Department of Statistics defines intangible investment as expenses for intangible assets, which are used for more than one year to purchase and to build. According to INTAN-Invest intangible investment consists of two parts: 1) traditional intangible investment that meets nationally recognized criteria for intangible assets - computer software, entertainment, literary and artistic originals, mineral explorations; and 2) new intangible investment, which is not included in the national accounts as an asset list - research and development, design, new financial products, advertising, market research, training, organizational capital. Thus, intangible assets are related to the acquisition or establishment of knowledge economy products and include the part of knowledge creation value. However, in 2002, in the forum "Usage of knowledge of European Union's associated countries' development" it was noted that almost all newly created products are coming from abroad, because the developed countries are investing billions in the development of science and technology. In Lithuania industry oriented to scientific research (technology) makes about $5 \%$ while in EU, the USA and Japan $20 \%-30 \%$ [5]. Intangible, technological assets and ability to innovate constantly, to develop new products, processes or services and new directions, is the key factor in creating the company's value [14]. Lithuanian executives identify tangible resources as the key material in creating company's additional value [19]. While analyzing Lithuania's statistical data, it was observed that the intangible investment compared to the tangible investment represents a small part of the total formed capital. (Gross fixed capital formation) (Fig. 1).

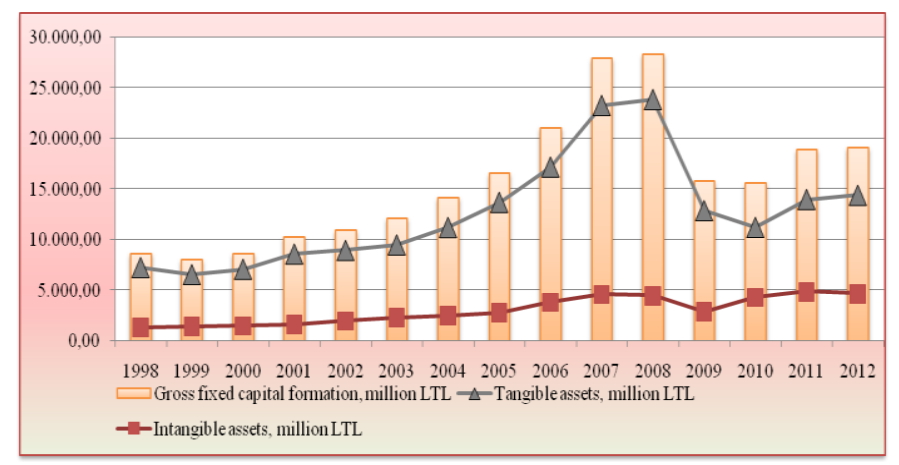

Fig. 1. Dynamics of intangible and tangible assets in the total capital, million LTL. Resource: developed by authors based on Euro stat, Lithuanian Department of Statistics, INTAN-Invest data ${ }^{1}$.

In Fig. 1 we can see that tangible assets during the years $1998-2012$ accounted for the largest share of developing capital from 7.3 million LTL to 14.4 million LTL. The biggest growth started from 2005 (13.7 million LTL) to 2008 (23.9 million LTL). However, in 2008, when the financial crisis started, the growth of tangible investment dramatically decreased to 11.0 million LTL (in 2009 it was 12.9 million LTL). Although intangible investment during 1998-2012 formed only a small part of the core capital - from 1.3 million LTL to 4.7 million LTL, but during the crisis the fall was less -1.3 million LTL, i.e., about $35.3 \%$, while tangible investment dropped by $46.0 \%$. This shows that during the crisis intangible assets remain the most attractive investment for companies and organizations.

Education spending plays an important role in knowledge creation. Education as a way of human quality improvement provides individual with more abilities and possibilities for effective self-realization, has important implications when

\footnotetext{
${ }^{1}$ Intangible assets are analyzed using INTAN-Invest and Lithuanian Department of Statistics data.
} 
regarding the person, not only as a separate social unit, but as one of the key factors in the country's economic potential development and at the peak of its realization [1]. In addition, research and development take an important role in knowledge creation. Obtaining of knowledge is directly linked to research and development (R\&D) [25]. Research and development is a systematic creative work, for storing knowledge and looking for ways to adjust it. Research and development as a resource of receiving new knowledge is an integral part of the innovation process. Summarizing authors claims about the importance of investment to knowledge creation, Fig. 2 reflects the knowledge value creation process.

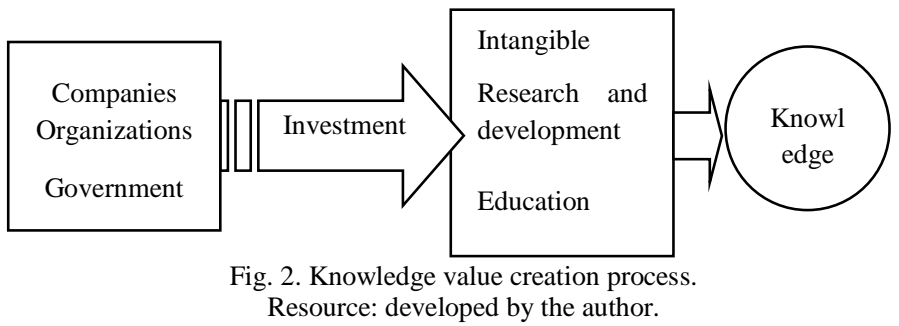

Fig. 2 shows that at a country level in the knowledge value creation process major investments are involved: intangible, education, research and development. Thanks to these investments new products and services are generated, we use them every day: new medicine, technological equipment, communication tools and more. Science, economics and education are very closely related to each other [22]. Interaction of science and education supplements society with competitive scientists. Scientific and economic interaction strengthens country's economic competitiveness. The result of education and economic interaction is well-trained professionals, declining unemployment and competitive country's economy. Effective process of knowledge creation and its use is impossible without the comprehensive government attention and support [12]. Particularly significant is social contract between the government, maintenance and support of educational institutions.

Knowledge generating investment dynamics during $1998-$ 2012 is shown in Fig. 3.

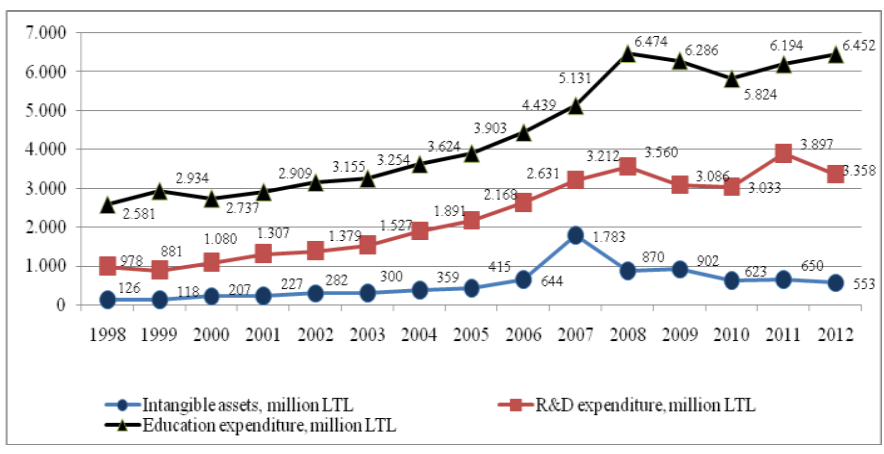

Fig. 3. Knowledge generating investment.

Resource: developed by authors based on Euro stat, Lithuanian Department of Statistics, INTAN-Invest data.

As shown in Fig. 3, during the years 1998-2012, expenditure on education increased by 3.871 million LTL, for scientific research and development it increased by 2.380 million LTL and for intangible assets -427 million LTL. The data show that the majority of knowledge-generating assets go on educational expenditure, followed by spending on research and development, the minimum goes to intangible assets. Analyzing these assets together allows to evaluate their impact on the country's economic growth.

\section{KNOWLEDGE GENERATING INVESTMENT'S IMPACT ON THE GDP GROWTH}

Investment in knowledge creation through science and technology, through effective education system show the competitiveness of a country or an organization, and this is the economy. The comparison of knowledge generating investment and GDP growth rates are presented in Fig. 4.

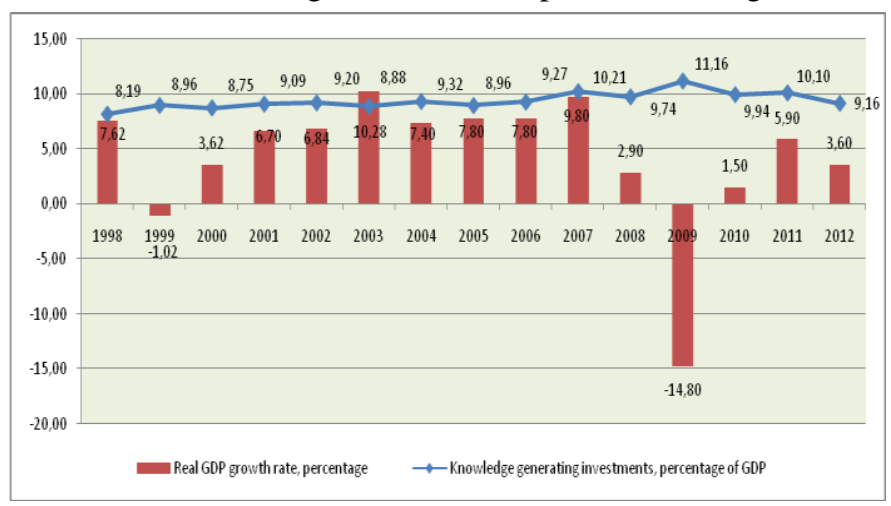

Fig. 4. The comparison of knowledge generating investment and GDP growth rates, \%. Resource: developed by authors based on Euro stat, Lithuanian Department of Statistics, INTAN-Invest, World Bank's statistical data ${ }^{2}$.

Fig. 4 reveals that when comparing knowledge-generating investments' dynamics with the GDP growth we can notice a relative growth of investment in knowledge creation by $0.97 \%$ points (from $8.19 \%$ to $9.16 \%$ ) during the year $1998-$ 2012, while GDP growth slowed down by $4.02 \%$ points (from $7.62 \%$ to $3.60 \%$ ). In order to evaluate these two variables i.e. knowledge-generating investment (further - KGI) and gross domestic product (GDP) across invocation we will use correlation and one-dimensional linear regression method. (Fig. 5).

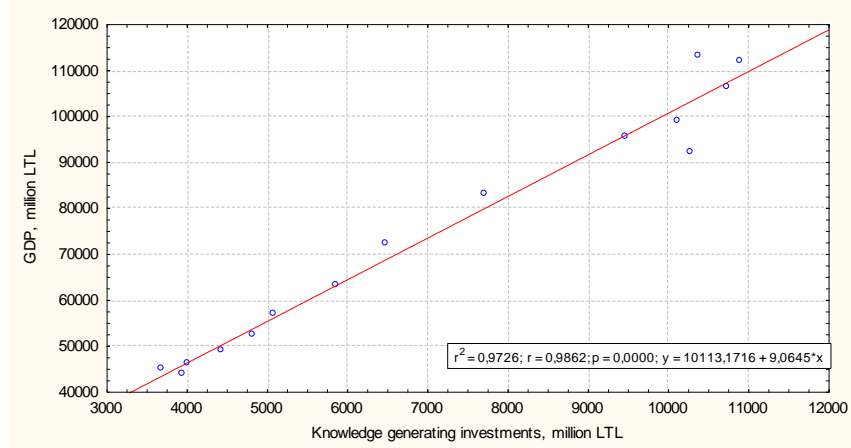

Fig. 5. Knowledge generating investment and GDP, million LTL interaction connection.

Resource: developed by authors.

\footnotetext{
${ }^{2}$ Note: Research involves the analysis of traditional intangible investment, which is indrawn into national accounts' list as a property.
} 
Fig. 5 shows that there is a very strong relation between KGI and GDP, because of correlation (r) coefficient which is 0.986 . In addition, the coefficient of determination $R^{2}=0.973$ indicates that $97.3 \%$ of GDP growth depends on the variation of the variable (knowledge-generating investment) and $2.7 \%-$ from other non-assessed variables changes. One-dimension linear regression model $y=10113 ; 1716+9.0645 x$ shows that knowledge-generating investment growth of 1 million GDP would increase to about 9.1 million LTL. Knowledgegenerating investment consist of three resources: intangible investment, education expenditure, research and development investment which are very important to evaluate each change of these variables to GDP growth. To that end, between dependent variable - GDP and independent one - intangible investment, education expenditure, research and development investment is carried out by correlation analysis with the help of multiple linear regression model coefficients' estimation (Table I).

TABLE I

GDP AND KNOWLEDGE-GENERATING VARIABLE INTERACTION RESEARCH $1998-2012$

\begin{tabular}{|c|c|c|c|c|}
\hline $\begin{array}{l}\text { Description } \\
\text { of the } \\
\text { meaning }\end{array}$ & $\begin{array}{l}\text { GDP, } \\
\text { million } \\
\text { LTL (Y) }\end{array}$ & $\begin{array}{l}\text { Intangible } \\
\text { investment, } \\
\text { million } \\
\text { LTL (X1) }\end{array}$ & $\begin{array}{l}\text { Education } \\
\text { expenditure } \\
\text { million } \\
\text { LTL (X2) }\end{array}$ & $\begin{array}{l}\text { Research and } \\
\text { development, } \\
\text { million LTL } \\
\quad \text { (X3) }\end{array}$ \\
\hline Amount $\Sigma$ & 1130056 & 8059 & 65887 & 33988 \\
\hline Average & 75337 & 537 & 4392 & 2266 \\
\hline \multicolumn{2}{|c|}{ Correlation $(r)$} & 0.71 & 0.97 & 0.99 \\
\hline \multicolumn{2}{|c|}{$\begin{array}{l}\text { Elasticity in percent } \\
\bar{E}_{1}=b_{1} \frac{-}{x_{1}} \\
\frac{y}{y}\end{array}$} & 11.4 & 33.6 & 6.7 \\
\hline $\begin{array}{l}\text { Sample statis } \\
t=\mid r \sqrt{\frac{n-2}{1-r}}\end{array}$ & cs (t) & 3.6 & 14.3 & 20.6 \\
\hline \multicolumn{3}{|c|}{$\begin{array}{l}\text { Stjudent's distribution with degrees of } \\
\text { freedom } 0.025 ; 13 \text { the significance of } \\
\text { variables }\end{array}$} & \multicolumn{2}{|c|}{ Theoretical value 2.16} \\
\hline \multicolumn{3}{|c|}{$\begin{array}{l}\text { Fisher's distribution with degree of } \\
\text { freedom } 0.05 ; 3 ; 11 \\
\text { The adequacy of the regression model } \\
F=\frac{\sigma_{\hat{y}}^{2}}{\sigma_{l i k}^{2}}\end{array}$} & \multicolumn{2}{|c|}{$\begin{array}{c}\text { Theoretical value } 3.9 \text { / actual } \\
\text { value } 4.59\end{array}$} \\
\hline \multicolumn{3}{|c|}{ Coefficient of determination $R^{2}$} & \multicolumn{2}{|c|}{0.781} \\
\hline \multicolumn{3}{|c|}{$\begin{array}{l}\text { Corrected coefficient of determination } \\
\bar{R}^{2}=R^{2}-\frac{m}{n-m-1}\left(1-R^{2}\right)\end{array}$} & \multicolumn{2}{|c|}{0.761} \\
\hline \multicolumn{3}{|c|}{$\begin{array}{l}\text { Fisher's distribution with degree of } \\
\text { freedom } 0.05 ; 3 ; 11 \text { significance of } \\
\text { determination coefficient } \\
F=\frac{R^{2}(n-m-1)}{\left(1-R^{2}\right)^{* 2}}\end{array}$} & \multicolumn{2}{|c|}{$\begin{array}{c}\text { Theoretical value } 3.59 \text { / actual } \\
\text { value } 27.94\end{array}$} \\
\hline \multicolumn{3}{|c|}{$\begin{array}{l}\text { Average approximation error, percent. } \\
\bar{A}=\frac{1}{n} \sum_{i}\left|\frac{\left(\mathrm{y}^{-}-\hat{\mathrm{y}}_{\mathrm{i}}\right)}{\mathrm{y}_{\mathrm{i}}}\right| * 100\end{array}$} & \multicolumn{2}{|c|}{$\begin{array}{c}\text { Theoretical value } 10 \text { / actual } \\
\text { value } 2.06\end{array}$} \\
\hline
\end{tabular}

Resource: developed by authors
The data presented in Table I show that between GDP and knowledge-generating variables, i.e., intangible investment $(r=0.71)$ link is direct and strong, education $(r=0.97)$, research and development expenditure $(r=0.99)$ link is direct and very strong. Since the correlation coefficient estimates are positive, this means that the growth of intangible investment (further-X1), education (further-X2), research and development (further $-\mathrm{X} 3$ ) expenditure should rise up the GDP. In order to determine the significance of linear correlation coefficient estimates, sample statistics $t$ has been used, which is compared using the Student's criteria, when the confidence level is $95 \%$. The evidence suggests that significance condition is valid for independent variables (X1 $t=3.66>2.16 ; \mathrm{X} 2 t=14.3>2.16 ; \mathrm{X} 3 t=20.6>2.16$ ), and correlation coefficients are key while independent variables are used to form multiple regression model:

$$
Y=12637.10+15.97 \mathrm{x}_{1}+5.76 \mathrm{x}_{2}+2.24 \mathrm{x}_{3}
$$

Calculated coefficient estimates show that

$>$ if intangible investment increased by 1 million LTL, GDP would increase by 15.97 million LTL;

$>$ if education expenditure increased by 1 million LTL, GDP would go up by 5.76 million LTL;

$>$ if research and development expenditure increased by 1 million LTL, GDP would go up by 2.24 million LTL.

Calculated determination coefficient $R^{2}-0.781$ indicates that $78.1 \%$ of GDP depends on the variables included in the model change, and $21.9 \%$ from the change of other nonassessed variables. To evaluate the significance of determination coefficient, actual value of the Fisher criterion has been used $(F=27,94>3,29)$, which is higher than theoretical value of the Fisher criterion, it means that variables' correlation is significant and multiple regression model adequacy is trusty $(F=4.59>3.29)$.

$>$ If intangible investment increased by $1 \%$ from the average 5.37 million LTL, GDP should increase by 11 . $4 \%$ from the average, i.e., 8588 million LTL;

$>$ If educational costs increased by $1 \%$ from the average 43.92 million LTL, GDP should increase by $33.6 \%$ from the average, i.e., 25313 million LTL;

$>$ If research and development increased by $1 \%$ from the average 22.66 million LTL, GDP should increase by $6.7 \%$ from the average, i.e., 5048 million LTL.

$$
\left|\bar{E}_{1}=11,4\right|<\left|\bar{E}_{2}=33,6\right|>\left|\bar{E}_{3}=6,7\right|
$$

Based on this one can formally make a conclusion that education expenses have a greater impact on GDP growth than intangible investment, research and development, whereas intangible investment has a greater effect on GDP growth than research and development. Taking the average approximation error, its value is about $2.06 \%$. Consequently, the formed multiple regression model is suitable for prediction and planning because the approximation error does not exceed $10 \%$. 
In summary we can imply that in the knowledge economy the company's main asset is intangible and the ability to obtain and use knowledge is increasingly important for countries' economic competitiveness, but we also need effective educational system that enables lifelong learning, develops new approaches to innovation and brings together scientists and entrepreneurs to develop new competitive products and services. Due to this investment economic value is created together with the country's economic growth.

\section{CONCLUSION}

Knowledge creation is not a phenomenon in the knowledge economy. Main knowledge value creating investment, such as intangible, education, research and development is analyzed in the research literature. Due to this investment new products and services are created that enhance competitive advantage in the international arena. Science, education and economy are integral to each other seeking for new scientific inventions, educated professionals, competitive products and high level of economic development. Although in Lithuania formation of intangible assets in the core capital is less than tangible assets, during the crisis period, intangible resources remain the most attractive investment. Moreover, in knowledge generating investment, expenses on education, research and development take the biggest share, while, intangible investment gets the smallest one.

The study showed that knowledge generating investment's impact on GDP growth is very strong. And $97.3 \%$ of GDP growth depends on the variation of the knowledge-generating investment and $2.7 \%$ from other non-assessed variables changes. The set of the knowledge generating investment impact revealed that the relationship between the GDP and intangible investment is direct and strong, while among education, research and development - direct and very strong. Correlation analysis showed that for economic growth the knowledge generating investment's impact is not only strong but also significant and the formed multiple regression model is adequate in real situation and suitable for forecasting and planning.

In order to strengthen the knowledge-generating investment to the GDP growth in Lithuania, it is necessary to increase investment in education and the creation or development of new and existing technologies. It is due to this investment that the economy is gaining greater competitive advantage over other countries.

\section{REFERENCES}

[1] Bagdanavičius, J., “Žmogiškasis kapitalas,” Technologija: Vilnius, 2002.

[2] Blankas, I. A., "Investiciju valdymas," Kijevas: Nikos centras. Elga, 2002.

[3] Cekanavicius, L. and Kasnauskiene, G., "Too High or Just Right? CostBenefit Approach to Emigration Question," Inzinerine EkonomikaEngineering Economics (1), 2009, pp. 28-36.

[4] Chow, C., Deng, F. and Ho, J., "The openness of knowledge sharing within organizations: a comparative study of the United States and the People's Republic of China," Journal of Management Accounting Research, vol. 12, no. 1, 2000, pp. 65-95.

http://dx.doi.org/10.2308/jmar.2000.12.1.65

[5] Corrado, C. A. and Hulten, C. R., "How do you measure a "Technological Revolution"?" Available: http://www.conferenceboard.org/pdf_free/AEA2010.pdf, 2010.
[6] “European Round table," Available: http://www.ert.eu.

[7] Daugèlienè, R., "Transformation of the Economy: the expression of knowledge - based economy penetration and the Assesment models," Wissensbasierte okonomie im zeitalter des internet. Technische Universitata Koszalin, Kompetenzzentrum EU - Osterwiterubg am BiG Greifswald, 2005.

[8] Daugèlienè, R and Kriščiūnas, K., "Pecularities of knowledge-based economy assesment: theoretical approach," Juxtaposition of European Union Enlargement and Lisbon Processes. Kaunas: Technologija, 2004.

[9] Daugèlienè, R. and Volodzkiene, L., "The Assesment peculiarities of human resource impact to the knowledge economy's development," Enlarged European Union in house of Europe: new internal and external problems, 2010.

[10] INTAN-Invest. Available: http://www.intan-invest.net.

[11] Karazijienè, Ž. and. Sabonienè, A., "Žinių visuomenès formavimas žinių ekonomikos kontekste," Ekonomika ir vadyba, no. 15, 2010, pp. 566-573.

[12] Krikščiūnas, K and Daugèlienè, R., “Žiniomis grịstos ekonomikos link: žinių raiška ir skvarba," Technologija: Vilnius, 2006.

[13] Hicks, R. C., Dattero, R. D. \& Galup, S. D., "A metaphor for knowledge management: explicit islands in a tacit sea," Journal of Knowledge Management, vol. 11, no. 1, 2007, pp. 5-16. http://dx.doi.org/10.1108/13673270710728204

[14] Liepé, Z and Sakalas, A., "The three-loop learning model appliance in new product development," Inzinerine Ekonomika-Engineering Economics, no. 3, 2008, pp. 73-80.

[15] Li, Y. H., Huang, J. W. \& Tsai, M. T., "Entrepreneurial orientation and firm performance: The role of knowledge creation process," Industrial Marketing Management, vol. 38, 2009, pp. 440-449. http://dx.doi.org/10.1016/i.indmarman.2008.02.004

[16] Lee, L. T. and Sukoco, B. M., "The effects of entrepreneurial orientation and knowledge management capability on organizational and knowledge effectiveness in Taiwan: The moderating role of Social Capital," International Journal of Management, vol. 24, no. 3, 2007 pp. 549-572.

[17] Lithuanian Department of Statistics. Available: http://www. stat.gov.lt/

[18] Makstutis, A., "The problems of development of national state," Journal of Business Economics and Management, vol. 8, no. 1, 2007, pp. 63-68.

[19] Mačerinskienè, I and Survilaite, S., "Intellectual capital as the main factor of company's value added," Intelektine ekonomika, vol. 5, no. 4(12), 2011, pp. 560-574.

[20] Nonaka, I., "A dynamic theory of organizational knowledge creation," Organization Science, 5(1), 1994, pp. 14-37.

[21] Nonaka, I, Toyama, R. and Nagata, A., "A firm as a knowledge-creating entify: A new perspective on the theory of the firm," Industrial and Corporate Change, vol. 9, no. 1, 2000, pp. 1-20. http://dx.doi.org/10.1093/icc/9.1.1

[22] Pranulis, V. P., "Marketing studies and science in Lithuania," Inzinerine Ekonomika-Engineering Economics, (1), 2008, pp. 22-28.

[23] Paris forum "Usage of knowledge European Union's associated countries development," Available: www.verslobanga.lt/lt/zb.dow nload/... /Butkaus_pranesimas.ppt

[24] Snitka, V., "Mokslinių tyrimų, technologijų, inovacijų politika ir žinių ekonomikos plètra," Kaunas. Available: http://www.microsys.ktu.Lt/ Snitka_prezentacijos/PDF/Snitka\%20Moksliniu\%20tyrimu_technologiju _Inovaciju\%20politika_ziniu\%20ekonomika\%201.pdf, 2002.

[25] Strazdas, R., Jakubavičius, A., Gečas, K. Inovacijos (finansavimas rizikos kapitalas). Vilnius: Lietuvos inovacijų centras. Available: http://www. inovacijos.lt/ inopagalba/cms/65lt.pdf, 2003.

[26] Sakalas, A. and Venskus, R., "Interaction of Learning Organization and Organizational structure," Inzinerine Ekonomika-Engineering Economics (3), 2007.

[27] Sajeva, S. and Jucevicius, R., "Determination of Essential Knowledge Management System Components and their Parameters," Social Sciences, 1 (67), 2010, pp. 80-91.

[28] Teece, D. J., "Capturing value from knowledge assets: The new economy, markets for know-how, and intangible assets," California Management Review, 40 (3), 1998, pp. 55-79.

Dalia Rudytė is a Doctor of Social Sciences and an Associate Professor with Economics Faculty of Social Sciences, Šiauliai University. Her research interest is financial market developments of Lithuania integration into international markets. She is the author of over forty scientific articles, and has developed six methodical scientific books. She has participated in research projects in Denmark, Great Britain, Latvia, Estonia etc.

E-mail: daliarudyte@gmail.com 
$2014 / 26$

Rita Bužinskienė holds a PhD in Social Sciences and is a Lecturer with Accounting and Finance Department, Siauliai State College and Northern Lithuania College. She has 12 years experience of working as Financier with trading and manufacturing companies. Her research interests are: Evaluation of intangible resources in financial reporting in the context of globalization; Accounting for intangible assets in accordance with international accounting standards; The impact of intangible assets, the market value assessment.

E-mail: ritabuzin@gmail.com 